requires close collaboration and an effective referral system among haemophilia centres, obstetricians, and genetic centres offering DNA analysis. The fairly rapid introduction of first trimester prenatal diagnosis using the DX13 probe has been helped by the availability of the well established method of prenatal diagnosis by fetal blood sampling at 18 weeks' gestation, which provides an alternative back up when data on families are not informative.

We thank all the staff of the Hospital for Sick Children, Great Ormond Street, and Royal Free Hospital haemophilia centres; Sister Caroline Tubridy for home visits; Dr K L Rogers, South London Transfusion Centre, for blood grouping; Dr Frances Rotblat, Royal Free Hospital, for the fetal VIII:C antigen assay; and Mrs Melanie Barham for administrative and secretarial help. $\mathrm{KH}$ is supported by a grant from Action Research for the Crippled Child. RCW is supported by a Medical Research Council grant, and RJAP is supported by grants from the National Birthday Trust, the Sir Halley Stewart Trust, and the Katherine Bishop Harman award 1983.

\section{References}

1 Carter CO. Monogenic disorders. I Med Genet 1977;14:316-20.

2 Colman RW, Hirsh J, Marder VJ, Salzman EW, eds. Hemostasis and thrombosis. Basic principles and clinical practice. Philadelphia: Lippincott, 1982:76.

3 Spakes RS, Berg C, Evans HJ, Klinger HP, eds. Human gene mapping 7 (1984): seventh workshop on human gene mapping. Cytogenet Cell Genet 1984;37:1-4.

4 Graham JB. Genotype assignment (carrier detection) in the haemophilias. Clinical Haematology 1979;8:115-45.

5 Mibashan RS, Rodeck CH, Thumpston JK, et al. Plasma assay of fetal factor VIIIC and IX for prenatal diagnosis of haemophilia. Lancet 1979; i: 1309.

6 Simoni G, Brambati B, Danesino C, Rossella F, Terzoli GL, Fraccaro M. Hum Genet 1983;63: 349-57.

7 Gosden JR, Mitchell AR, Gosden CM, Rodeck CH, Morsman JM. Direct vision chorion biopsy and chromosome-specific probes for determination of fetal sex in first trimester prenatal diagnosis. Lancet 1982; ii: 1416-9.

8 Williamson R, Eskdale J, Coleman DV, Niazi M, Loeffler FE, Modell BM. Direct gene analysis of chorionic villi: a possible technique for first-trimester antenatal diagnosis of haemoglobinopathies. Lancet 1981;ii:1125-7.

9 Harper K, Winter RM, Pembrey ME, Hartley D, Davies KE, Tuddenham EGD. A clinically useful DNA probe closely linked to haemophilia A. Lancet 1984;ii:6-8.

10 Gitschier J, Wood WI, Goralka TM, et al. Characterization of the human factor VIII gene. Nature 1984;312:326-30

11 Gitschier J, Drayna D, Tuddenham EGD, White RL, Lawn RM. Genetic mapping and diagnosis of haemophilia $\mathrm{A}$ achieved through a Bcll polymorphism in the factor VIII gene. Nature of haemophilia A

12 Gitschier J, Lawn RM, Rotblat F, Goldman E, Tuddenham EGD. Antenatal diagnosis and carrier detection of haemophilia A using factor VIII gene probe. Lancet $1985 ; \mathrm{i}: 1093-4$.

13 Antonarakiss S, Copeland KL, Carpenter RJ, et al. Prenatal diagnosis of haemophilia A by factor VIII gene analysis. Lancet 1985 ; $1: 1407-9$.

14 Kunkel LM, Smith KD, Boyer SH, et al. Analysis of human Y-chromosome specific reiterated DNA in chromosome variants. Proc Natl Acad Sci USA 1977;74:1245-9.

15 Rodeck CH, Morsman JM, Nicolaides KH, McKenzie C, Gosden CM, Gosden JR. A singleoperator technique for first trimester chorion biopsy. Lancet 1983;ii:1340-1.

16 Ward RHT, Modell B, Petrou M, Karagozlou F, Douratsos E. Method of sampling chorionic villi in the first trimester of pregnancy under the guidance of real time ultrasound. $\mathrm{Br} \mathrm{Med} J$ 1983;286:1542-4.

17 Southern E. Detection of specific sequences among DNA fragments separated by gel electrophoresis. F Mol Biol 1975;98:503-17.

18 Winter RM, Tuddenham EGD, Goldman E, Matthews KB. A maximum likelihood estimate of the sex ratio of mutation rates in haemophilia A. Hum Genet 1984;64:156-9.

19 Akhmeteli MA, Aledort LM, Alexiants S, et al. Methods for the detection of haemophilia carriers: a memorandum. Bull WHO 1977;55:675-702.

20 Pembrey ME, Davies KE, Winter RM, et al. Clinical use of DNA markers linked to the gene for Duchenne muscular dystrophy. Arch Dis Child 1984:59:208-16.

21 Winter RM. The calculation of genetic risks in X-linked recessive conditions using programmable calculators. Clin Genet 1980;17:171-5.

$22 \mathrm{Ott} \mathrm{J}$. Estimation of the recombination fraction in human pedigrees: efficient computation of the likelihood for human linkage studies. Am $\mathcal{F}$ Hum Genet 1974;26:588-97.

23 Price RA, Kidd KK. Utilising automated methods to improve estimates of recurrence risk with linked genetic markers. Am J Med Genet 1984;17:621-5.

24 Lathrop GM, Lalouel JM. Easy calculations of Lod scores and genetic risks on small computers. Am F Hum Genet 1984;36:460-5.

25 Rotblat F, Tuddenham EGD. Immunologic studies of factor VIII coagulant activity. I. Assays based on a haemophilic and an acquired antibody to VIIIC. Thromb Res 1981;21:431-45.

26 Jeffreys AJ, Wilson V, Thein SL. Hypervariable "minisatellite" regions in human DNA. Nature 1985;314:67-73.

27 Oberie I, Camerino G, Heilig R, et al. Genetic screening for hemophilia A (classic hemophilia) with a polymorphic DNA probe. $N$ Engl f Med 1985;312:682-6.

(Accepted 23 fuly 1985)

\title{
Small bowel biopsy for malabsorption: comparison of the diagnostic adequacy of endoscopic forceps and capsule biopsy specimens
}

\author{
A S MEE, MARGARET BURKE, A G VALLON, J NEWMAN, P B COTTON
}

\begin{abstract}
Biopsy specimens of the small bowel were obtained from $\mathbf{4 0}$ patients suspected of having malabsorption. Four different techniques were used at a single session-namely, endoscopic biopsy of the descending duodenum using paediatric and standard size forceps and suction capsule biopsy of the descending duodenum and the proximal jejunum. Specimens were compared for size, adequacy, and ability to confirm or exclude mucosal abnormality. Fourteen patients had villous atrophy. In all patients four biopsy specimens were obtained with paediatric endoscopic forceps and four with standard endoscopic forceps. No capsule
\end{abstract}

Department of Gastroenterology and Bland Sutton Institute of Pathology, Middlesex Hospital and Medical School, London W1N 8AA

A S MEE, MD, MRCP, senior registrar

MARGARET BURKE, MRCPATH, lecturer

A G VALLON, MB, MRCP, honorary senior registrar

J NEWMAN, MRCPATH, senior lecturer

P B COTTON, MD, FRCP, consultant physician

Correspondence to: Dr A S Mee, Battle Hospital, Reading, Berks RG3 IAG. biopsy specimen was retrieved from the duodenum in three patients and from the jejunum in five patients. Specimens were considered to be adequate in 36 patients when paediatric forceps were used, in 39 when standard forceps were used, in 28 on duodenal capsule biopsy, and in 32 on jejunal capsule biopsy.

This study indicates that the most reliable method for diagnosing or excluding villous atrophy is endoscopic forceps biopsy of the descending duodenum, provided that at least four specimens are obtained with standard size forceps.

\section{Introduction}

Mucosal biopsy of the small intestine is an essential investigation in patients suspected of having diffuse disease of the small bowel. The most common indication for biopsy is to confirm (or refute) a diagnosis of gluten sensitive enteropathy and to monitor the mucosal response to exclusion of gluten.

The suction biopsy capsule is widely used' to provide specimens from the proximal jejunum that are large enough for correct orientation, histological interpretation, and biochemical study. ${ }^{2}$ Nevertheless, the method has disadvantages. The need for radiological screening makes it unsuitable for repeated use in young 
children and potentially pregnant women, and there may be some discomfort when the procedure is prolonged. The technique fails in up to $10 \%$ of cases, ${ }^{3}$ and the specimen may be inadequate for histological interpretation in up to $25 \% .^{4}$ To overcome these disadvantages several authors have studied biopsy specimens taken from the descending duodenum with endoscopic forceps to assess small intestinal mucosa in both healthy ${ }^{5}$ and diseased states. ${ }^{4-9}$ In these studies, however, the size of the forceps used has lacked uniformity, the results have been compared retrospectively with a different group of patients, ${ }^{4}$ and the number of specimens obtained has often been small or has varied. ${ }^{69}$

Two main questions arise from this. Are endoscopic biopsy specimens adequate for histological assessment, and can gluten sensitive enteropathy be diagnosed (and excluded) in specimens taken from the second part of the duodenum instead of the proximal jejunum? To try to answer these questions we performed a prospective study of biopsy specimens obtained by four different techniques at the same session.

\section{Methods}

Forty adults ( 27 women, 13 men; mean age $47 \cdot 9$ (range 20-74) years) suspected of having disease of the small bowel underwent biopsy of the upper small intestine as part of their routine investigation.

All patients were routinely sedated with pethidine $50 \mathrm{mg}$ and diazepam 5 $10 \mathrm{mg}$ given intravenously. A plastic oversleeve and obturator ${ }^{10}$ were then introduced into the oesophagus and the obturator withdrawn. A Crosby capsule was muzzle loaded through a GIF-Q endoscope ${ }^{11}{ }^{12}$ and the endoscope then passed down through the oversleeve and into the second part of the duodenum. Air was aspirated and the endoscope withdrawn into the stomach, leaving the capsule in the duodenum. After the capsule had been fired both endoscope and capsule were removed, leaving the oversleeve in place. After the capsule had been unloaded the endoscope was reinserted into the duodenum and eight biopsy specimens taken from the second part of the duodenum distal to the papilla of Vater, four using small forceps designed for paediatric endoscopes (Olympus FB-IK, cup diameter $1 \cdot 77$ $\mathrm{mm}$, capacity $2.18 \mathrm{~mm}^{3}$ ) and four using larger standard sized forceps designed for adult endoscopes (Olympus FB-3K, cup diameter $2.35 \mathrm{~mm}$, capacity $5 \cdot 1 \mathrm{~mm}^{3}$ ). The endoscope was removed, leaving the oversleeve in

TABLE I-Numbers of patients in whom adequate biopsy specimens were obtained ( $n=40$ )

\begin{tabular}{lccc}
\hline \multirow{2}{*}{$\begin{array}{c}\text { Technique } \\
\text { used }\end{array}$} & \multicolumn{3}{c}{ Adequacy } \\
\cline { 2 - 4 } & Adequate & Inadequate & Not obtained \\
\hline $\begin{array}{l}\text { Paediatric forceps } \\
\text { Standard forceps }\end{array}$ & 36 & 4 & \\
Capsule biopsy: & 39 & 1 & 3 \\
Duodenum & 28 & 9 & 5 \\
Jejunum & 32 & 3 &
\end{tabular}

TABLE II-Number of adequate biopsy specimens and accurate diagnoses using different biopsy techniques

\begin{tabular}{lcccc}
\hline & \multicolumn{4}{c}{ Biopsy technique } \\
\cline { 2 - 5 } & $\begin{array}{c}\text { Paediatric } \\
\text { forceps }\end{array}$ & $\begin{array}{c}\text { Standard } \\
\text { forceps }\end{array}$ & $\begin{array}{c}\text { Duodenal } \\
\text { capsule }\end{array}$ & $\begin{array}{c}\text { Jejunal } \\
\text { capsule }\end{array}$ \\
\hline $\begin{array}{l}\text { No of adequate } \\
\text { specimens }\end{array}$ & $69 / 160$ & $97 / 160$ & $28 / 40$ & $32 / 40$ \\
$\begin{array}{l}\text { No of accurate } \\
\text { diagnoses }(n=40)\end{array}$ & 36 & 39 & 28 & 32 \\
\hline
\end{tabular}

place, and the Crosby capsule again muzzle loaded through the endoscope and placed in the distal duodenum. The endoscope and oversleeve were withdrawn and the capsule screened radiographically into a position just distal to the ligament of Treitz, where a further biopsy specimen was obtained. Apart from obtaining the final capsule specimen the whole procedure seldom took longer than 20 minutes.

For histological evaluation all biopsy specimens were placed on a fibre free card and fixed in $10 \%$ formol saline. Only the jejunal capsule biopsy specimen was orientated at the time of biopsy by examination under a dissecting microscope. All specimens were processed routinely and embedded on edge in paraffin wax. Sections 4-5 $\mu \mathrm{m}$ thick were taken at two depths, stained with haematoxylin and eosin, and examined under a light microscope by two independent observers unaware of the origin of the specimens.

\section{DEFINITIONS}

Adequacy-A biopsy specimen was considered to be adequate for histological evaluation if it was orientated with villi cut perpendicular to the plane of section and with minimal fragmentation.

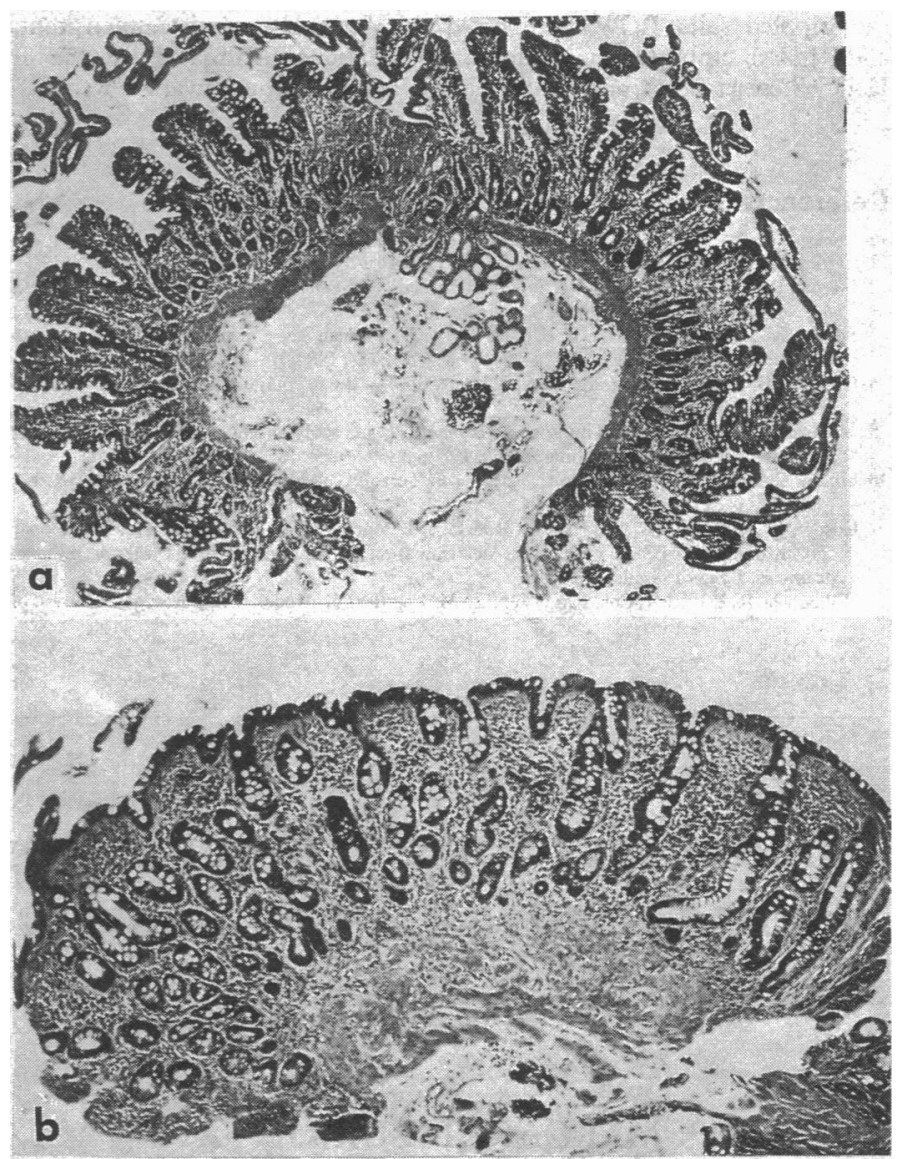

FIG 1-Adequate duodenal biopsy specimens obtained by endoscopy showing (a) normal villous architecture and $(b)$ subtotal villous atrophy. Haematoxylin and eosin $\times 12 \cdot 5$ (original magnification).

Accuracy-Diagnostic accuracy was assessed by comparing the histopathological features of the specimens from different sites in each patient. The standard jejunal capsule specimen was used as the reference specimen both for comparative purposes and for routine diagnosis.

Morphometry and statistical evaluation-Semiquantitative morphometry using a Reichert-Jung Kontron Digiplan was performed to obtain an estimate of the size of the specimen as indicated by the surface area $\left(\mathrm{mm}^{2}\right)$ of the largest portion of tissue on each slide. The sizes of specimens were compared by one way analysis of variance.

\section{Results}

ADEQUACY

Tables I and II summarise the results.

Paediatric forceps biopsy-Four specimens were taken from each patient. At least one specimen adequate for diagnosis was obtained in 36 patients (90\%) (fig 1). Four adequate biopsy specimens were obtained from two patients, three from seven, two from 14, and one from 12; in four patients the specimens were inadequate. The mean surface area of the specimens was 


\section{BRITISH MEDICAL JOURNAL VOLUME $291 \quad 21$ SEPTEMBER 1985}

$1.7(\mathrm{SD} 0.56) \mathrm{mm}^{2}$ (range $0.7-2.9 \mathrm{~mm}^{2}$ ). In the four patients in whom all the specimens were considered to be unsuitable for adequate histological assessment these specimens were all greater than $2 \cdot 2 \mathrm{~mm}^{2}$ in size. Problems in interpretation were due to fragmentation and poor orientation of tissue (fig 2).

Standard forceps biopsy-At least one biopsy specimen adequate for diagnosis was available in 39 patients $(97 \cdot 5 \%)$. Four adequate specimens were obtained from eight patients, three from seven, two from 19, one from six, and none from one. The mean surface area of all specimens was $2 \cdot 2$ $(0.53) \mathrm{mm}^{2}\left(1 \cdot 0-3 \cdot 6 \mathrm{~mm}^{2}\right)$.

Capsule biopsy of the duodenum-No specimen was obtained in three cases. Specimens were adequate for diagnosis in only 28 patients $(70 \%)$. Failure to
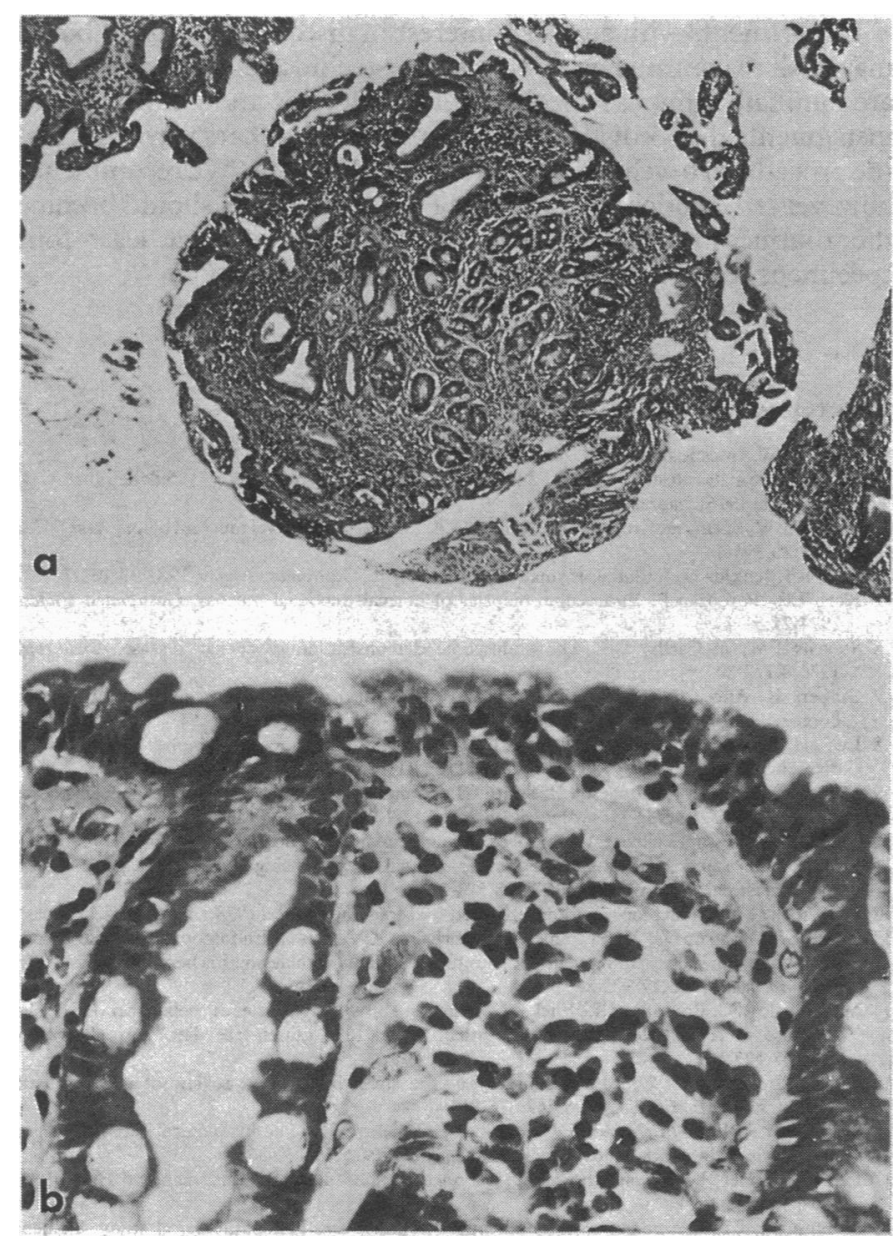

FIG $2-(a)$ Inadequate duodenal biopsy specimen obtained by endoscopy showing poorly orientated inflamed mucosa. Haematoxylin and eosin $\times 12.5$ (original magnification). (b) Detail of ( $a$ ) showing enterocyte abnormality, excess intraepithelial lymphocytes, and inflamed plasma cell infiltrate in lamina propria suggesting villous atrophy. $\times 125$ (original magnification). obtain an adequate specimen occurred regularly early in the series (nine out of 25). This was thought to result from insufflation of air into the duodenal lumen during endoscopy, which kept the walls apart and prevented a sufficiently large piece of tissue from entering the capsule port. Aspiration of air before the capsule was fired in the remaining 13 cases resulted in an improvement in the number of suitable specimens (12 out of 15). The mean surface area of all specimens was $2.9(1.9) \mathrm{mm}^{2}\left(0.7-8.7 \mathrm{~mm}^{2}\right)$.

Capsule biopsy of the jejunum - No specimen was obtained in five cases, and the tissue was considered to be inadequate in a further three cases. Specimens were thus adequate in 32 patients $(80 \%)$. The mean surface area of the specimens was $6 \cdot 9(4 \cdot 72) \mathrm{mm}^{2}\left(0 \cdot 6-21 \cdot 8 \mathrm{~mm}^{2}\right)$.

\section{HISTOLOGICAL ASSESSMENT}

Fourteen patients had villous atrophy: in eight this was partial and in six subtotal. Twelve patients were ultimately diagnosed as having gluten sensitive enteropathy, based on the result of the initial biopsy together with evidence of clinical and histological improvement at the time of repeat biopsy after two months of a gluten free diet. In one patient from the Middle East partial villous atrophy was thought to be due to tropical enteropathy, but no follow up could be obtained. Another patient with partial villous atrophy failed to respond to a gluten free diet, and no diagnostic conclusion was reached.

\section{ACCURACY}

Table III shows the correlation of diagnoses between all four sets of biopsy specimens. In the 14 patients with villous atrophy 10 diagnoses were based on the capsule biopsy specimens from the jejunum. In the remaining four patients these specimens were inadequate or not obtained, although there was complete agreement between the three other techniques in three of the patients. In the remaining patient only the specimen from the duodenum obtained by capsule biopsy was adequate for assessment.

The histological appearances of villous atrophy were thus similar in all four sets of biopsy specimens in five patients and in three sets in two patients in whom a fourth biopsy specimen could not be obtained. Good correlation was also noted in three sets in a further four patients in each of whom a fourth set was inadequate; in all four, however, villous atrophy was suspected from the degree of inflammation and enterocyte abnormality present. Two other patients showed minor variation in the degree of villous atrophy.

\section{OTHER FINDINGS}

Chronic non-specific inflammation without accompanying enterocyte abnormality was noted in a substantial number of endoscopic biopsy specimens taken from the second part of the duodenum. These changes were not sufficient to interfere with the primary diagnosis in any patient.

\section{STATISTICAL EVALUATION}

The differences in size between the duodenal and jejunal capsule biopsy specimens and between the paediatric and standard forceps biopsy specimens were significant at the $1 \%$ level.

TABLE III-Correlation of histological diagnosis with different biopsy techniques in 14 patients with partial $(P)$ or subtotal $(S)$ villous atrophy

\begin{tabular}{|c|c|c|c|c|c|c|}
\hline Case No & $\begin{array}{l}\text { Paediatric } \\
\text { forceps }\end{array}$ & $\begin{array}{l}\text { Standard } \\
\text { forceps }\end{array}$ & $\begin{array}{c}\text { Capsule biopsy } \\
\text { (duodenum) }\end{array}$ & $\begin{array}{l}\text { Capsule biopsy } \\
\text { (jejunum) }\end{array}$ & $\begin{array}{c}\text { Final histological } \\
\text { diagnosis }\end{array}$ & $\begin{array}{l}\text { Final clinical } \\
\text { diagnosis }\end{array}$ \\
\hline $\begin{array}{r}4 \\
6 \\
10 \\
11 \\
13 \\
19 \\
24 \\
26 \\
29 \\
31 \\
33 \\
35 \\
38 \\
40\end{array}$ & $\begin{array}{c}\mathbf{S} \\
\mathbf{P} \\
\mathbf{P} \\
\mathbf{P} \\
\mathbf{S} \\
\text { Inadequate } \\
\mathbf{P} \\
\text { Inadequate } \\
\mathbf{S} \\
\mathbf{S} \\
\mathbf{S} \\
\mathbf{P} \\
\mathbf{P} \\
\mathbf{P}\end{array}$ & $\begin{array}{c}\mathbf{S} \\
\mathbf{P} \\
\mathbf{P} \\
\mathbf{P} \\
\mathbf{S} \\
\mathbf{S} \\
\mathbf{P} \\
\text { Inadequate } \\
\stackrel{S}{S} \\
\mathbf{S} \\
\mathbf{S} \\
\mathbf{P} \\
\mathbf{P} \\
\mathbf{P}\end{array}$ & $\begin{array}{c}\mathbf{P} \\
\mathbf{P} \\
\text { Inadequate } \\
\mathbf{P} \\
\text { Inadequate } \\
\mathbf{P} \\
\mathbf{P} \\
\mathbf{P} \\
\mathbf{S} \\
\mathbf{S} \\
\mathbf{S} \\
\mathbf{P} \\
\mathbf{P} \\
\text { Inadequate }\end{array}$ & $\begin{array}{c}\mathbf{S} \\
\mathbf{P} \\
\mathbf{P} \\
\mathbf{P} \\
\mathbf{S} \\
\mathbf{S} \\
\mathbf{P} \\
\text { Inadequate } \\
\text { No specimen } \\
\text { Inadequate } \\
\stackrel{\mathbf{P}}{\mathbf{P}} \\
\text { No specimen } \\
\mathbf{P}\end{array}$ & $\begin{array}{l}\mathbf{S} \\
\mathbf{P} \\
\mathbf{P} \\
\mathbf{P} \\
\mathbf{S} \\
\mathbf{S} \\
\mathbf{P} \\
\mathbf{P} \\
\mathbf{S} \\
\mathbf{S} \\
\mathbf{S} \\
\mathbf{P} \\
\mathbf{P} \\
\mathbf{P}\end{array}$ & $\begin{array}{c}\text { GSE } \\
\text { GSE } \\
\text { GSE } \\
\text { GSE } \\
\text { GSE } \\
\text { GSE } \\
\text { GSE } \\
\text { GSE } \\
\text { GSE } \\
\text { GSE } \\
\text { GSE } \\
\text { Tropical enteropathy } \\
\text { No diagnosis } \\
\text { Dermatitis herpetiformis } \\
\text { with GSE }\end{array}$ \\
\hline
\end{tabular}




\section{Discussion}

In this study endoscopic biopsy (in which at least four specimens were taken with standard sized forceps) proved to be more accurate than capsule techniques for the diagnosis or exclusion of villous atrophy. The main advantage was the guarantee of obtaining specimens, as the capsule technique in the jejunum failed in eight cases $(20 \%)$. This figure seems high and may have been adversely influenced by insufflation of air, although the delay between endoscopy and firing of the capsule makes this unlikely. Nevertheless, a similarly low success rate $(76 \%)$ was reported in a retrospective series of 346 capsule biopsies taken in the usual manner. ${ }^{4}$ Previous studies have shown that specimens obtained with endoscopic forceps are adequate for histological evaluation ${ }^{5}$ and diagnosis of mucosal abnormality in individual patients. ${ }^{79}$ Authors differ over whether this approach is more ${ }^{13}$ or less accurate ${ }^{4}$ than a conventional capsule biopsy. Those who found it less accurate, however, did not always use standard sized forceps or take four or more specimens; our study suggested that both of these factors were important. Specimens obtained with paediatric forceps were less reliable, although this disadvantage might perhaps be overcome by taking more specimens or by routine attempts at orientation when use of a small endoscope is desirable-for example, in young children.

The variation in severity of the mucosal lesion in gluten sensitive enteropathy is well documented, being most pronounced in the duodenum and proximal jejunum, where the concentration of dietary gluten is highest, and minimal or absent in the distal jejunum. ${ }^{14}$ Only minor variations in the degree of villous atrophy should therefore be found in the duodenojejunal area, a finding confirmed both in our study and in those of others. ${ }^{7} 9$

Biopsy specimens obtained endoscopically are small and difficult to orientate, making it difficult to assess villous architecture as recommended for capsule biopsy specimens. ${ }^{15}$ When multiple specimens are obtained, however, careful handling during embedding and examination of at least two depths should yield histological sections of sufficient quality for a confident diagnosis to be made or at least suspected from the degree of inflammation and enterocyte abnormality present.' Both Whitehead et al and Lee and Toner emphasised the difficulty in diagnosing gluten sensitive enteropathy in biopsy specimens taken from near the duodenal bulb, ${ }^{16}{ }^{17}$ where the changes of active duodenitis, together with villous blunting normally seen in that area, may overlap with those induced by gluten. Holdstock et al pointed out, however, that there are usually sufficient differences in both cellular infiltrate and epithelial abnormality for this distinction to be made. ${ }^{9}$ This is especially so in biopsy specimens taken distal to the papilla of Vater, where the histopathological changes of duodenitis rarely occur and where Brunner's glands and lymphoid aggregates are less common. ${ }^{16}$

Biopsy of the small bowel is part of the routine practice of all by suction biopsy capsule from the proximal jejunum. The endodepartments of gastroenterology, and specimens are usually obtained scopic method, however, has several practical advantages, including the fact that patients can be added to a routine endoscopy list, the speed of obtaining specimens, accuracy of targeting, opportunity screening. The disadvantages of the sedation required for endoscopy seem to be only a minor drawback. The size of the specimens is not a problem, and elaborate biochemical analyses are feasible ${ }^{8}$; indeed, the volume of tissue that can be retrieved is determined only by the number of specimens taken. Nevertheless, newer endoscopes with large biopsy channels $(3.7 \mathrm{~mm}$ diameter or greater) have been developed for therapeutic endoscopy, and larger endoscopic biopsy specimens could therefore be obtained if required. The use of an enteroscope to examine and biopsy the proximal jejunum would not appear to offer any appreciable advantage. may wish to continue using the capsule techniques with which they are familiar: some use special steerable devices and guide wires or instruments that provide multiple specimens; others leave much of the procedure to well trained nurses or technicians. We recommend, however, that endoscopic biopsy of the small bowel should become the routine in most departments, provided that at least four specimens are taken with standard sized forceps.

\section{References} Saunders, 1976; chapter 57

3 Smith RBW, Sprinz H, Crosby WH, Sullivan BH. Peroral small bowel mucosal biopsy. Am J Med 1958;25:391-4.

4 Scott BB, Jenkins D. Endoscopic small intestinal biopsy. Gastrointest Endosc 1981;27:162-7. Korn ER, Foroozan P. Endoscopic biopsies of normal duodenal mucosa. Gastrointest Endosc 1974;21:51-4.

6 Stevens FM, McCarthy CF. The endoscopic demonstration of coeliac disease. Endoscopy 1976;8:177-80.

7 Gillberg R, Ahren C. Coeliac disease diagnosed by means of duodenoscopy and endoscopic duodenal biopsy. Scand $\mathcal{J}$ Gastroenterol 1977;12:911-6.

8 Lee JH, Griffiths WJ, Zantout I, Welsh JD. Adequacy of endoscopic biopsy specimens for disaccharidase assays. Dig Dis Sci 1978;23:1129-31.

9 Holdstock G, Eade OE, Isaacson P, Smith CL. Endoscopic duodenal biopsies in coeliac disease and duodenitis. Scand $\mathcal{F}$ Gastroenterol 1979;14:717-20.

10 Cotton PB. Overtubes (sleeves) for upper gastrointestinal endoscopy. Gut 1983;24:863-6.

11 Prout BJ. A rapid method of obtaining a jejunal biopsy using a Crosby capsule and gastrointestinal fibrescope. Gut 1974;15:571-2.

12 Holdstock G. Jejunual biopsy without the need for screening. Lancet 1978;i:1236-7.

13 Gillberg R, Kastrup W, Mobacken H, Stockbrugger R, Ahren C. Endoscopic duodenal biopsy compared with biopsy from the upper jejunum in patients with dermatitis herpetiformis. Scand f Gastroenterol 1982;17:305-8.

14 MacDonald WC, Brandbor LL, Flick AL, Trier JS, Rubin CE. Studies of coeliac sprue. IV. The response of the whole length of the small bowel to a gluten-free diet. Gastroenterology 1964;47:573-89.

15 Rubin CE, Dobbins WO. Peroral biopsy of the small intestine: a review of its diagnostic usefulness. Gastroenterology 1965;49:676-97.

16 Whitehead R, Roca M, Meikle DD, Skinner J, Truelove SC. The histological classification of duodenitis in fibreoptic biopsy specimens. Digestion 1975;13:129-36.

17 Lee FD, Toner PG. Biopsy pathology of the small intestine. London: Chapman and Hall, 1980 166-74.

18 Kreuning J. Chronic non-specific duodenitis. A clinical and histopathological study. Leiden University of Leiden, 1978. (MD thesis.)

(Accepted 4 June 1985) for full endoscopic evaluation, and lack of necessity for $x$ ray

Departments with a special interest in disease of the small bowel

1 Sheehy TW. Intestinal biopsy. Lancet 1964;i:959-62.

2 Shiner M. Small intestinal biopsy. In: Bockus HL, ed. Gastroenterology. Philadelphia: W B

\section{YEARS AGO}

A horrible misadventure, resulting in the death of a little boy, aged five, and the serious injury of another child, which has recently taken place in the Scarborough Workhouse, points to culpable negligence on the part of the authorities of that institution. From evidence tendered at an adjourned inquest, it appears that the boys in the workhouse are bathed every Saturday night, and that on the previous Saturday the bath had been prepared by two men named Atkinson and Garnett. Six buckets of hot and two of cold water were placed in the bath. A boy, aged fourteen, lifted the deceased into the bath, but he immediately jumped out, whereupon Atkinson placed him in the water again. The deceased cried out that the water was too hot, but Atkinson thrust him down, taking hold of his hands and legs. The skin came off his thighs and left side, and on removal from the bath he was found to be so seriously injured that medical treatment was unavailing. Another boy who was put into the bath was not sufficiently recovered to attend the inquest. The coroner was of opinion that the deceased met his death through misadventure, and that there was no ground for supposing that any criminal blame attached to Atkinson and Garnett. The jury, however, whose notions of

justice were less hampered by judicial obstacles, with a laudable desire that the case should be the subject of another inquiry, returned a verdict of manslaughter against Atkinson, and censured his assistant. The real criminal is undoubtedly the master or other official responsible for the rude and irregular manner in which the bathing of children of tender years appears to have been carried out in the workhouse. In institutions where the consultation of the wishes of individual bathers is prohibited by disciplinary or other considerations, a thermometer is an absolutely necessary adjunct of the bath-room. For use in unscientific hands, the mercurial column should be unobscured by the divisions of Fahrenheit or Réaumur, and marked only with a single clear line to indicate the desired temperature. It is indeed devoutly to be hoped that the Scarborough workhouse is the only institution of its kind in which the thumb of a thick-skinned adult is considered an instrument of sufficient thermometric delicacy and trustworthiness for determining the temperature of children's baths. (British Medical Fournal 1885;ii:307.) 